\title{
Key technologies and equipment for contaminated surface/groundwater environment in the rural river network area of China: integrated remediation
}

\author{
Han Wang ${ }^{1}$, Tianbei Wang ${ }^{1}$, Gang Xue ${ }^{2}$, Jiang Zhao ${ }^{1}$, Weiwu Ma ${ }^{3}$, Yajie Qian², Min Wu' ${ }^{1}$ Zhuoran Zhang ${ }^{1}$, \\ Pin $\mathrm{GaO}^{2}$, Changqing Su${ }^{3}$, Bingnian Zong ${ }^{1}$, Junwu Yu', Jingsong $\mathrm{Guo}^{4}$ and Yayi Wang ${ }^{1 *}$ (C)
}

\begin{abstract}
To realize the integrated remediation of SW/GW and soil in the rural river network area, the integrated remediation in rural river network area project (IR-RRNA), funded by the Ministry of Science and Technology of the People's Republic of China, has been launched. In eastern China, the rural river network area (RRNA) is an anthropic active area characterized by its rapid economic development and high gross national product. However, the water environmental pollution in these areas is increasingly severe, which has greatly hindered their sustainable development. Especially, the frequent interactions between surface/groundwater (SW-GW) have intensified the pollution migration and transformation in RRNA. The IR-RRNA (2019-2022) will apply the related interdisciplinary and methodological knowledge to elucidate the transportation and transformation of pollutants in water and soil during SW-GW interaction and develop remediation technologies of surface water, groundwater, and soil suitable for the RRNA. In this way, to realize the remediation technologies integration for surface/groundwater and soil in RRNA and implementing application demonstration. Meanwhile, a technical guideline will be compiled for the integrated remediation suitable for the RRNA. This project is conducive to addressing the urgent environmental problems as well as promoting rural economic revitalization and ecological environment optimization.
\end{abstract}

Keywords: The rural river network area, Environmental remediation, SW-GW interaction, Soil remediation, The integrated remediation

\section{Introduction}

The river network is formed by the river mainstreams and their tributaries in the river basin, which is the result of the interaction between the environment and human activities. River networks have both ecological and social benefits for regional development, in particular in the

\footnotetext{
*Correspondence: yayi.wang@tongji.edu.cn

${ }^{1}$ State Key Laboratory of Pollution Control and Resources Reuse,

Shanghai Institute of Pollution Control and Ecological Security, College of Environmental Science and Engineering, Tongji University, Siping Road,

Shanghai 200092, People's Republic of China

Full list of author information is available at the end of the article
}

human-modified landscapes. However, in recent decades, river networks have suffered extensive destruction due to the anthropic activities of urbanization and industrialization, and this issue is especially serious in many developing countries [1-3].

Rural areas in plain river network areas possess an increasingly important status as they are the main producer of food and other natural resources for urban areas. The management of urban river systems is considered at an administrative region scale which plays a key role in the economic well-being of people living in both rural and urban areas. However, with the rapid urbanization and industrialization, rural communities face more 
pressures and risks from agricultural livelihoods, climate change, new technologies, commodity prices, environmental regulations, and economic conditions.

Rural development is hence a hot topic and challenging issue for human beings since the regional development has become more imbalanced between urban and rural areas in terms of population change, economic development, access to services, and social outcomes [4]. Accordingly, differential approaches have been proposed in worldwide for planning rapid and sustainable rural development. The strategies to cope with rural development have attracted wide attention and the differential approach for the planning of rural development has been proposed. For example, Participatory rural appraisal (PRA) has been launched, which describes approaches and methods for growing family to enable local people to share, to plan, and to act, by deep analyzing the status of the local people's life and living conditions, to plan and to act; Working With People (WWP) have been developed and implemented, and its connotation is that development projects, both in emerging countries and in the European Union, have to be developed by the people and not for the people $[5,6]$. In China, the rural development means gradual change of developing rural villages into modern villages, as western developed countries have done. In 2013, the Ministry of Agriculture launched "the Beautiful Village Project" to promote sustainable development of rural areas, which has emphasized on the importance of protecting and preserving natural, landscape, and cultural resources protecting and preserving, was hence developed. Therefore, the strategies to properly manipulate rural development are urgently required to effectively promote the environmental quality in the rural area.

The Yangtze River Delta (YRD) and the Pearl River Delta (PRD) are two Chinese regions with the highest river network density (the total length of rivers per square kilometer) (Fig. 1). Specifically, the values of the river density for these two deltas are both above $2.0[7,8]$. Take the YRD (with a high river density of 6.7), for example, the YRD is located in the plain river network area where major national city clusters bearing national strategies, but it faces the great challenge of the severe water environment pollution issue [9]. According to the measurement results reported by state of the environment in China by Ministry of Ecology and Environment of People's Republic of China (2019) (http://www.mee.gov.cn/ hjzl/sthjzk/zghjzkgb/), most of the rivers and lakes in the Yangtze River Delta, such as Taihu Lake, exhibited mild eutrophication [10]. Compared with urban river network areas, rural rivers are generally more remote, narrower, and more complex. Due to the different investments in river restoration, the rural river restoration lags that of urban rivers, and the capital investment and daily management are also insufficient. Pollutants are usually discharged into the rivers through surface runoff or drainage ditches without treatment. Indeed, it is reported that the effective treatment of domestic sewage in rural areas of China was only $11 \%$ [11]. The main manifestations of the water environmental pollution are as follows: (1) the
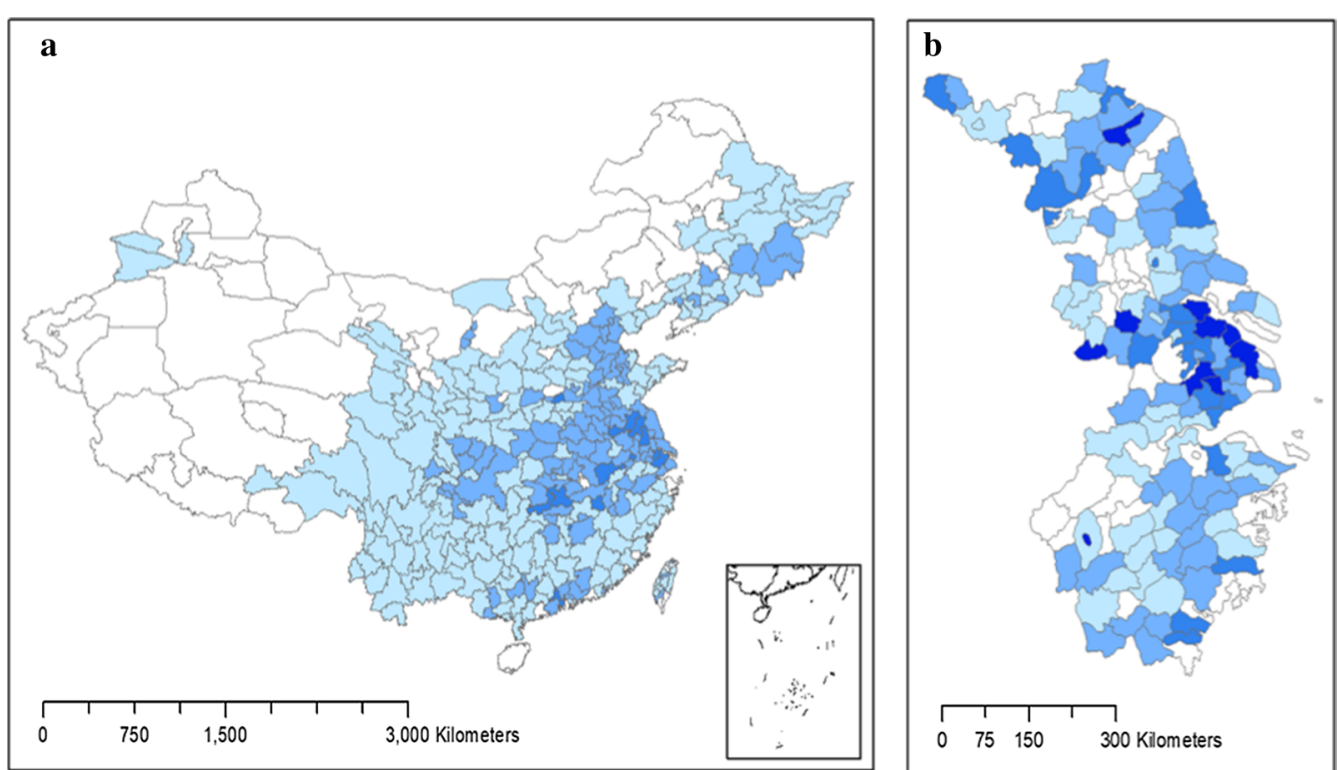

Fig. 1 Maps of drainage density $\left(\mathrm{km}^{-1}\right)$ for the river networks in China (a) and the YRD (b). A density of river networks is the total length of rivers per square kilometer, representing the river distribution density 
river system is seriously divided, leading to poor water connectivity and weak hydrodynamics; (2) the encroachment of river course frequently occurs due to the rapid economy development and the high pollution load into rivers; and (3) black and smelly water, and eutrophication problems of water bodies are prominent, and the water function areas that meet the national standard rate are few. Indeed, these problems have become the major bottleneck hindering the sustainable development of the plain river network area $[12,13]$. In January 2019, a country-level action plan for the protection and restoration of the Yangtze River released by the Ministry of Ecology and Environment and the National Development of the People's Republic of China, which clearly declared that the ecological and environmental improvement of the Yangtze River will be at the core of future work. Therefore, efficient control strategies are urgently needed to promote the quality of the water environment in rural plain river network areas.

It should be noted that the boundary zone of surface and subsurface is a complex environmental system where the mass (including pollutant) transformation occurs actively because of the active exchange of surface water and groundwater [14]. This situation is especially significant in the plain river network area in China where the underground water tables are generally high at -1 to $-3 \mathrm{~m}$ [15]. Surface water bodies, such as streams, lakes, and reservoirs, frequently interact with groundwater, and their interaction is of great importance in the hydrologic processes of river basins [16]. Even a small exchange between surface water and groundwater $(\mathrm{SW}-\mathrm{GW})$ can deliver a noteworthy contribution of solutes to a groundwater body, causing severe pollution interaction. Moreover, the surface runoff, unsaturated zone movement, and other actions can offer the way through which pollutants move from the surface/groundwater to soil [17]. The soil layer is an important ecosystem that protects both groundwater and surface water from contamination due to its good filtering function, but it can also be contaminated if the pollutant from groundwater or surface water exceeds its carrying environmental capacity. Therefore, if the surface water in plain river network area is contaminated with undesired substances (e.g., heavy metals, organic pollutants), it is likely that these pollutants can move to different environmental compartments, e.g., soil, surface, and groundwater, and ultimately produce great negative impacts on human health, climate change, biodiversity, and food safety. The changing and complex contamination status in RRNA requires the efficient integration of diverse environmental techniques and equipment.

In this circumstance, the Ministry of Science and Technology of the People's Republic of China (MOST) launched "green livable village program," to improve the rural living environment and to promote the coordination of agricultural production, living condition, and ecological conservation. In the environment monitoring and remediation in rural (EMR-rural) project, one of the subprojects in "green livable village program" is the restoration of the contaminated surface water and groundwater bodies to meet the requirements of water environment improvements in the rural river network areas [18]. This project focuses on research and development of the integrated remediation of key technologies and equipment for contaminated surface/ groundwater environment in the rural river network area of China.

The integrated remediation in rural river network area (IR-RRNA) project duration is 38 months (20192022), consists of 3 partners from China, including Tongji University, Central South University, and Donghua University. The IR-RRNA will focus on to (1) apply interdisciplinary and methodological knowledge to elucidate the transportation and transformation of pollutants in water and soil during SW-GW interaction; (2) develop key technologies of surface water, underground water, and soil environmental remediation in rural river network area; (3) implement the remediation technologies integration for surface/groundwater and soil in rural river network area and implementing application demonstration; and finally (4) compile technical guidelines for integrated remediation of surface/groundwater and soil suitable for the rural river network area.

\section{Current research status of environmental remediation in the rural river network area}

The Web of Science Core Collection annually collects thousands of journals to provide various records for each publication, including author information, journals, citation, and institutional affiliation, from multiple disciplines for bibliometric analysis. Different keywords were set to search and collect publications in the past ten years (2010-2019); the number of environmental remediation publications is shown in Fig. 2.

In the present study, the search for "surface water remediation," "groundwater remediation," or "soil remediation" all resulted in high numbers of publications and a rapid growth rate. However, only less than $1 \%$ of the studies focus on the "rural" or "river network" area. Also, the studies aimed to the remediation technologies for combined pollution are only less than 300 in recent 10 years ("Surface water + Groundwater," "Surface water + Soil," or "Groundwater + Soil"), and there is still a lack of research on integrated Surface water/Groundwater/Soil remediation. 


\begin{tabular}{|c|r|r|r|r|}
\hline Years & Surfacewater & Ground water & Soil \\
\hline 2019 & 2303 & 826 & 5228 \\
\hline 2018 & 2424 & 925 & 4677 \\
\hline 2017 & 2250 & 840 & 4038 \\
\hline 2016 & 1775 & 832 & 3844 \\
\hline 2015 & 1269 & 721 & 3179 \\
\hline 2014 & 912 & 582 & 2604 \\
\hline 2013 & 873 & 593 & 2563 \\
\hline 2012 & \\
\hline 2011 & 736 & 562 & 2330 \\
\hline 2010 & 567 & 444 & 1882 \\
\hline Total & & 489 & 434 & 1791 \\
\hline
\end{tabular}
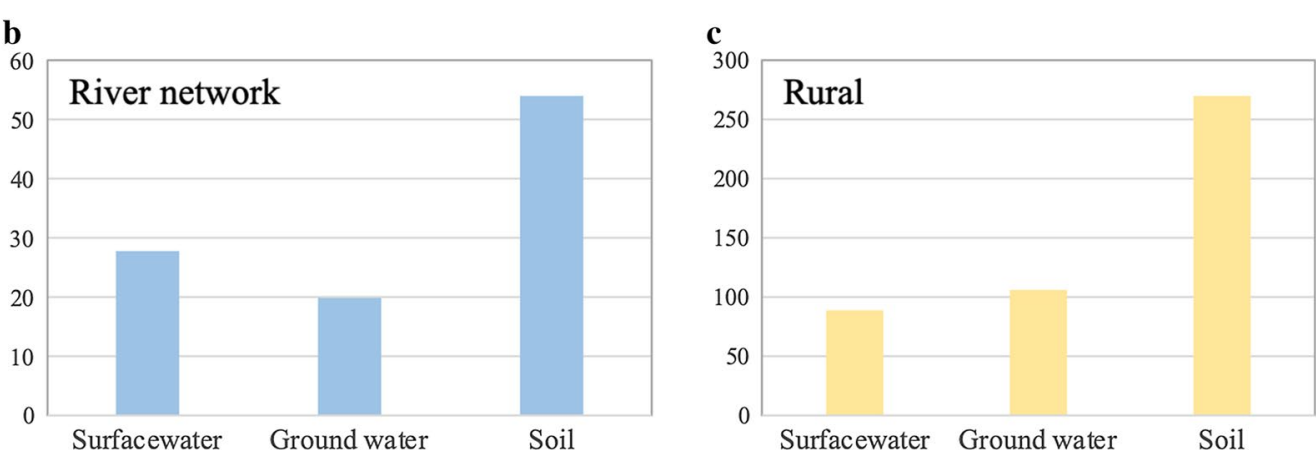

Fig. 2 a Records for the environmental remediation terms, including surface water, groundwater, and soil, filtered by publication period (2010 to 2019); b records for environmental remediation in river network area; c records for environmental remediation in the rural area

\section{Current research status of surface water remediation}

Surface water pollution has become a severe threat to water resource sustainability and ecological safety in the world [19]. However, as surface water has a large amount and widely distribute, it could not be remediated by traditional centralized treatment technology, such as traditional coagulation sedimentation for the polluted surface water (e.g., adsorption, extraction, ion exchange, and membrane separation). Moreover, the contaminated surface waters are generally characterized by a relatively low concentration of pollutants compared to that of raw wastewater, e.g., total nitrogen $(\mathrm{TN})<10 \mathrm{mg} / \mathrm{L}$ and total phosphorus $(\mathrm{TP})<1.0 \mathrm{mg} / \mathrm{L}$, so it might not be effective and economic to use the treatment technologies and equipment used for domestic sewage or industrial wastewater treatment [20]. Therefore, it is urgent to develop novel remediation technologies to prevent the deterioration of surface water quality (e.g., eutrophication) and maintain a healthy aquatic ecosystem.

In recent decades, a variety of studies have been carried out to remove contaminants from surface waters, including physical, chemical, and ecological methods (Table 1). Physical methods generally include dredging sediment, mechanical algal removal, aeration, and water diversion, by which surface water pollution can be mitigated temporarily but without persistency effects [21, 22]. Chemical remediation requires chemical agents and adsorbents to change the redox potential and $\mathrm{pH}$ in surface water, by which suspended substances and organic matter in surface water can be adsorbed and precipitated [23, 24]. The chemical reaction between agents and pollutants will separate and recover harmful substances in water, or convert them into harmless substances. Although the chemical method can quickly function, it needs to add a large number of chemical agents that are expensive and prone to cause secondary pollution (e.g., chemical sludge). Moreover, the produced chemical sludge requires to be treated in the sewage treatment plants, which brings about a large amount of extra work and troublesome operation of sewage treatment plants.

Ecological remediation is a new in-situ remediation technology that plants and microbes work together to remove environmental pollutants [25-28]. The mechanism of the in-situ ecological remediation is mainly to use the metabolic activities of plants and microbes to absorb, accumulate, or degrade environmental pollutants. In-situ 
Table 1 Key techniques for surface water remediation

\begin{tabular}{|c|c|c|}
\hline Remediation technique & Technique principle & Characteristics \\
\hline \multicolumn{3}{|l|}{ Physic method } \\
\hline Artificial aeration & $\begin{array}{l}\text { Increase the dissolved oxygen of the water body, reduce the } \\
\text { concentration of dissolved pollutants in water, improve } \\
\text { the living environment for aquatic organisms }\end{array}$ & High cost, need to be combined with other methods \\
\hline Sediment dredging & $\begin{array}{l}\text { Dredging the whole or part of the river with serious deposi- } \\
\text { tion to restore the normal function of the river }\end{array}$ & A large amount of engineering, disrupt existing bio-systems \\
\hline Mechanical algal removal & $\begin{array}{l}\text { Using ultrasonic wave to make algal cell burst, break algal } \\
\text { cell inside the airbag, make it lose float ability and precipi- } \\
\text { tate }\end{array}$ & Unsustainable method \\
\hline \multicolumn{3}{|l|}{ Chemical method } \\
\hline Chemical precipitation & $\begin{array}{l}\text { Adding iron salt or aluminum salt to produces chemical pre- } \\
\text { cipitation with inorganic phosphate through adsorption or } \\
\text { flocculation, controlling the eutrophication }\end{array}$ & \\
\hline Enhanced coagulation & $\begin{array}{l}\text { Add the appropriate coagulant and the decontamination is } \\
\text { carried out by adsorption, chemical precipitation, destabi- } \\
\text { lization flocculation, and adsorption bridging }\end{array}$ & $\begin{array}{l}\text { The addition of chemicals agents raises the cost and intro- } \\
\text { duce secondary pollution }\end{array}$ \\
\hline Acid-alkali neutralization & $\begin{array}{l}\text { Acidic or alkaline substances are added to the water body } \\
\text { to adjust the } \mathrm{pH} \text {, meet the growing need and species } \\
\text { reproduction in the aquatic ecosystem }\end{array}$ & \\
\hline Chemical algal removal & Add chemical algal removal agent, the effect is remarkable & Water table damage, high risk \\
\hline \multicolumn{3}{|l|}{ Ecological method } \\
\hline Constructed wetlands & $\begin{array}{l}\text { Simulates natural wetlands by extracting elements from } \\
\text { them for artificial enhancement }\end{array}$ & Large floor space \\
\hline Ecological floating bed & $\begin{array}{l}\text { Using the principle of soilless cultivation, plants are planted } \\
\text { in water and absorb nutrients directly from the water }\end{array}$ & Generally used to repair small rivers, lakes \\
\hline Ecological revetment & $\begin{array}{l}\text { Artificially reformed the river revetment to restore or } \\
\text { strengthen the ecological capacity of water, which can } \\
\text { protect the river bank and purify the water }\end{array}$ & Suitable for the long-term ecological remediation process \\
\hline
\end{tabular}

ecological remediation has many advantages when compared to other techniques, such as low costs, less adverse impacts on the environment, and no secondary production of pollutants. Indeed, many in-situ remediation processes, such as ecological floating bed techniques and constructed wetlands, have been developed for the bioremediation of polluted surface water and have exhibited satisfactory results $[27,28]$.

Ecological floating bed is a novel water remediation technology based on the traditional constructed wetland, which is featured with the dominant growth of aquatic plants or terrestrial plants on the surface of a water body. As an important component of the ecological floating bed, plants absorb the pollutant in water during their growth period and provide the attachment sites for microorganisms to grow through their developed plant roots. Sun et al. [29] investigated the remediation feasibility of ecological floating-bed systems using water spinach and sticky rice, and found that the total nitrogen removal rates reached $92.3 \%$ and $81.2 \%$, respectively. Meanwhile, introducing the appropriate carrier in the ecological floating bed can promote the growth of plants and improve their ability to resist contamination stress. A study adopting plant Acorus calamus L. in the ecological floating bed demonstrated that the green zeolite was the best substrate for Acorus calamus L. to uptake metals, and the removal efficiencies of $\mathrm{Cr}$ and $\mathrm{Cd}$ were up to $95.24 \%$ and $91.8 \%$, respectively [30].

\section{Current research status of groundwater remediation}

Groundwater and surface water have been managed as an isolated medium for a long time, but actually, they are hydrologically connected in terms of both water quantity and quality [31]. The physical interactions between groundwater and streams primarily depend on two factors: (i) the geological context and permeability degree of an aquifer in comparison to a streambed and (ii) the relationship between the river water level and piezometric level in the vicinity of the river. Generically speaking, the interactions between SW and GW take place in three basic ways: (i) steams gain water from the inflow of groundwater through the streambed (Gaining stream) (Fig. 3a); (ii) streams lose water to groundwater by outflow through the streambed (Losing stream) (Fig. 3b); (iii) do both (i) and (ii), gaining and losing stream. Thus, most of the groundwater contamination in shallow aquifers that are directly connected to surface water $[32,33]$. 
a

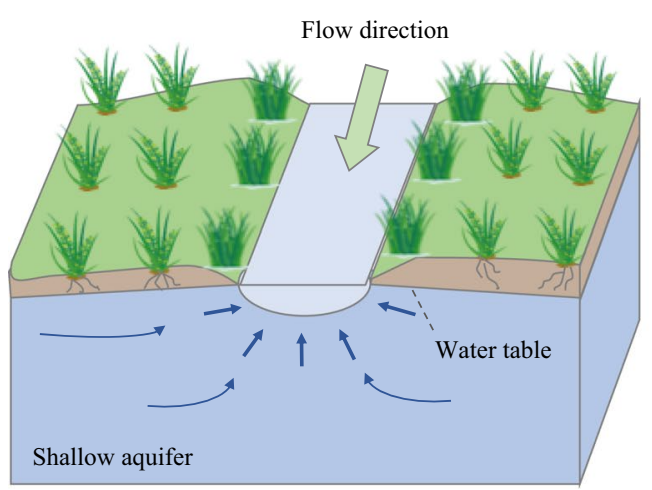

b

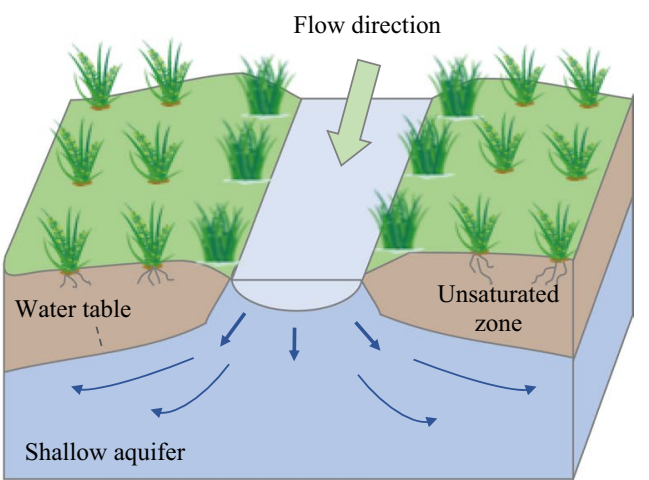

Fig. 3 The two type of interactions between SW and GW

Groundwater is a very important source of agricultural irrigation and the domestic supply of drinking water for both human beings and animals in the world. To ensure the safety and sustainability of groundwater resources, numerous remediation technologies have been developed to remove pollutants from groundwater (Table 2). Pump-treat is one of the earliest groundwater remediation strategies that widely applied previously [34, 35]. However, some factors in terms of the treatable pollutants, cost considerations, cleanup efficiency, and secondary contamination have become limitations to the successful remediation of the contaminated sites. Therefore, in recent years, the combination of pump-treat with other alternative technologies has been proposed, such as chemical oxidation processes and bioremediation, to enhance the removal efficiency and lower the operational cost [36, 37]. Some novel techniques have also been developed by integrating conventional treatments with modern technologies, such as nano-material technology [38]. It is reported that permeable reactive barriers (PRBs) with nano zero-valent iron (nZVI) immobilization and packaging materials have a good capability to

Table 2 Key techniques for groundwater remediation

\begin{tabular}{|c|c|c|}
\hline Remediation technique & Technique principle & Characteristics \\
\hline \multicolumn{3}{|l|}{ Ex situ } \\
\hline Pump and treatment & $\begin{array}{l}\text { Groundwater is extracted and sent to the sewage treat- } \\
\text { ment system for decontamination }\end{array}$ & Suitable for the treatment of soluble pollutants \\
\hline Excavation method & $\begin{array}{l}\text { The method of soil excavation can be used to treat and } \\
\text { remediate the polluted groundwater }\end{array}$ & Only suitable for a small range of groundwater pollution \\
\hline \multicolumn{3}{|l|}{ In situ } \\
\hline Bioremediation & $\begin{array}{l}\text { Utilize microorganisms to transform contaminants into less } \\
\text { harmful daughter-products }\end{array}$ & Long processing time, need the integrated application \\
\hline Air sparging & $\begin{array}{l}\text { Inject air into the aquifer, and the pollutants in the ground- } \\
\text { water move into the vadose zone with the air. Combine } \\
\text { with the soil vapor extraction method to treat the pollut- } \\
\text { ants in the groundwater }\end{array}$ & $\begin{array}{l}\text { Suitable for soil with good permeability and homogeneous } \\
\text { quality }\end{array}$ \\
\hline Electrokinetic remediation & $\begin{array}{l}\text { The charged ions of the metal undergo directional migra- } \\
\text { tion under the influence of the electric field force, and } \\
\text { the pollutants eventually gather together for centralized } \\
\text { treatment }\end{array}$ & Suitable for organic and heavy metal pollution \\
\hline Chemical oxidation & $\begin{array}{l}\text { Carried out by oxidizing reaction between oxidizing agent } \\
\text { and pollutant in groundwater }\end{array}$ & Easy to affect the geological and ecological environment \\
\hline Permeable reactive barrier & $\begin{array}{l}\text { A trench is excavated downstream of the hydraulic gradi- } \\
\text { ent of the groundwater to form a reaction wall. When the } \\
\text { sewage flows through the reaction wall, the pollutants in } \\
\text { the groundwater are adsorbed, oxidized, and biode- } \\
\text { graded }\end{array}$ & Low cost and large application scope \\
\hline
\end{tabular}


improve the decontamination efficiency [39, 40]. Also, the performance of PRBs filled with nZVI was satisfactory in the removal of heavy metal ions, such as mercury, chromium, lead, zinc, nickel, and copper, and the percentage of removal was usually $>90 \%$ [40]. Traditionally, the PRBs have dimensions of $<5 \mathrm{~m}$ in width (parallel to flow), $10 \mathrm{~m}$ in depth, and $50 \mathrm{~m}$ in length (transverse to flow), and these barriers are filled with reactive media. There are two designing patterns of PRBs for the practical applications: the funnel-and-gate pattern which with relatively expensive construct fee but allows for pockets of plumes widely distributed to be captured for treatment; the other one is the continuous gate pattern, which are easy to realize but only suitable for plumes with narrow widths [41]. Recent studies have focused on the modifications of these two original PRBs designs, such as filling new remediation materials and adopting multi-barrier concept, to broaden the applicational area of PRBs.

\section{Current research status of soil remediation}

In the river network area, the riparian zone is the transition area between land and aquatic ecosystems (Fig. 4), and its ability to provide aquatic habitat and process chemical (including contaminants) varied along with the varying water source [42]. Soil filtration in the riparian zones can mitigate the negative effects of non-point source pollution on water quality, and plant absorption is capable of improving interactions between the roots and pollutants (e.g., nitrogen, subordinately phosphorous, and heavy mental) [43]. Thus, a better understanding of the riparian zone and create corresponding effective soil remediation technology is significant if the water quality requires to be effectively managing.

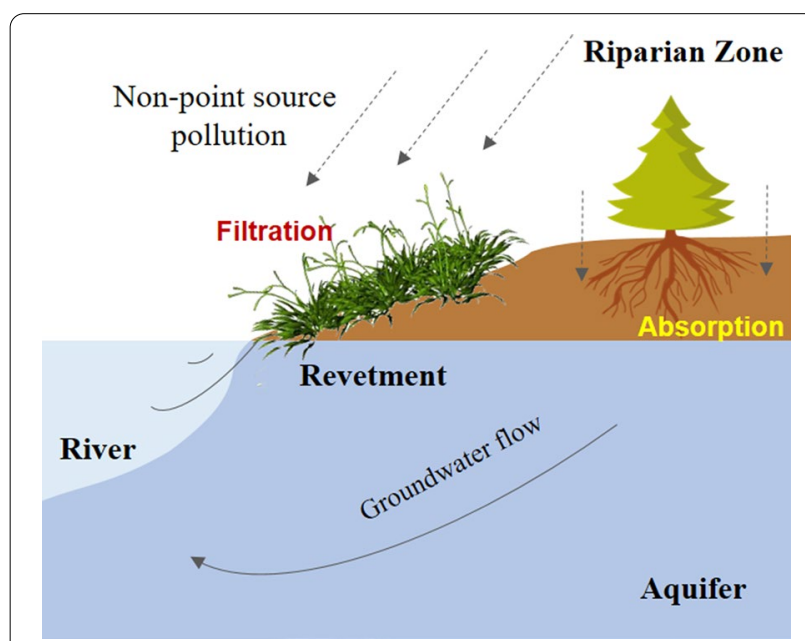

Fig. 4 Soil function on pollutant transfer between land and aquatic ecosystems in the riparian zone
Soil pollution could cause profound impacts on crop productivity and human health. Accordingly, investigation of the sources, fate, and occurrence of soil pollution, as well as the induced risks to human health, has been an important topic in the ecological environmental area [44]. The results of the National Soil Pollution Status Survey Bulletin show that the overall national soil environment is not optimistic and three main pollution characteristic have occurred. (i) The soil pollution in China is mainly inorganic pollution, followed by organic pollution; (ii) eight inorganic pollutants of cadmium, mercury, arsenic, copper, lead, chromium, zinc, and nickel have a point exceeding rate of $7.0 \%, 1.6 \%, 2.7 \%, 2.1 \%, 1.5 \%, 1.1 \%$, $0.9 \%$, and $4.8 \%$, respectively; and (iii) the soil pollution problems in some regions such as the YRD and the PRD are more prominent (National Soil Pollution Status Survey Bulletin) [45]. For example, the Dabaoshan mining area in Guangdong province has caused serious pollution of surrounding farmland and crops, leading to frequent illnesses in the downstream Shangba Village. Moreover, pollutants in the soil could affect the reproduction of plants, soil animals, and microorganisms, endangering the normal soil ecological process and ecosystem service functions [46].

The soil remediation techniques can be classified into two categories (i.e., in situ and ex situ), and are mainly affiliated to physical-chemical and ecological remediation (Table 3). The selection of the appropriate remediation technology depends on several factors, such as the characteristics of the hydrogeological environment, chemical and physical properties, of the contaminants, and financial resources. Due to the occurrence of complex compounds in soil, using the combined remediation technology (more than one) to comprehensively remediate the contaminated soil is often the case $[47,48]$.

Phytoremediation contains the processes of phytodegradation, phytoextraction, phytostabilization, phytostimulation, phytovolatilization, and rhizofiltration, to achieve extraction, degradation, or metabolization of toxic substances (Table 4). Phytoremediation has been increasingly used for soil remediation in recent years as it has a remarkable co-benefit, including providing a plant cover to the soil and reducing soil erosion. Cui et al. [49] conducted a phytostabilization experiment in polluted soil, and found that Pennisetum sinese successfully decreased soil availability of $\mathrm{Cu}$ and $\mathrm{Cd}$. A study of the methylation process of 2,4-DBP by rice plants showed that phytovolatilization of 2,4-DBP contributed to $41.7 \%$ of their total volatilization, enhancing the emission of contaminant from hydroponic solution into the atmosphere [50]. Moreover, in the practical pollution remediation process, adopting multiple phytoremediation technologies are more favorable to the removal of 
Table 3 Key techniques for soil remediation

\begin{tabular}{|c|c|c|}
\hline Remediation technique & Technique principle & Characteristics \\
\hline \multicolumn{3}{|l|}{ Physical-chemical remediation } \\
\hline Vapor extraction & $\begin{array}{l}\text { Drive air through the pores of the contaminated soil, } \\
\text { thereby entraining VOCs to the extraction system, } \\
\text { pumping to the ground, and then collecting and } \\
\text { processing }\end{array}$ & $\begin{array}{l}\text { Suitable for unsaturated areas, sites with strong permeabil- } \\
\text { ity, and volatile organic pollutants }\end{array}$ \\
\hline Thermal desorption & $\begin{array}{l}\text { The organic pollutants in the soil will accelerate decom- } \\
\text { position and volatilization during the heating process, } \\
\text { and the contaminated gas is extracted and collected } \\
\text { from the soil through the suction system to process }\end{array}$ & $\begin{array}{l}\text { Suitable for volatile organic matter and semi-volatile } \\
\text { organic matter }\end{array}$ \\
\hline Immobilization/stabilization & $\begin{array}{l}\text { Immobilization: encapsulating soil pollutants in a solid } \\
\text { material with complete structure; Stabilization: transfer } \\
\text { pollutants into a state or form that is not soluble, } \\
\text { transportable, or less toxic, reducing the bioavailability } \\
\text { of pollutants }\end{array}$ & Contaminants cannot be fundamentally removed \\
\hline Chemical redox & $\begin{array}{l}\text { Add oxidant or reducing agent to contaminated soil, } \\
\text { through oxidation or reduction, so that the pollut- } \\
\text { ants in the soil into non-toxic or relatively less toxic } \\
\text { substances }\end{array}$ & $\begin{array}{l}\text { Not suitable for remediation of heavy metal contaminated } \\
\text { soil }\end{array}$ \\
\hline Soil washing & $\begin{array}{l}\text { The eluent is injected into the contaminated soil, with } \\
\text { the help of chemical/biochemical solvents that can } \\
\text { promote the dissolution or migration of pollutants, } \\
\text { transfer pollutants from the soil phase to the liquid } \\
\text { phase. The wastewater from the elution system should } \\
\text { be further treated }\end{array}$ & $\begin{array}{l}\text { Not suitable for soil with a fine (clay/powder) content of } \\
\text { more than } 25 \%\end{array}$ \\
\hline \multicolumn{3}{|l|}{ Ecological remediation } \\
\hline Phytoremediation & $\begin{array}{l}\text { Use plants for extraction, rhizosphere filtration, volatiliza- } \\
\text { tion, and fixation to remove, transform, and destroy } \\
\text { pollutants in the soil, so that the polluted soil can } \\
\text { restore its normal functions }\end{array}$ & Long processing time and slow results \\
\hline Microorganism remediation & $\begin{array}{l}\text { The method of transforming, degrading, and removing } \\
\text { pollutants in the environment by using indigenous } \\
\text { microorganisms in the natural environment or artifi- } \\
\text { cially adding exogenous microorganisms }\end{array}$ & Suitable for integrated use with other methods \\
\hline
\end{tabular}

pollutants. For example, phytodegradation is always used to degrade organic pollutants, such as polycyclic aromatic hydrocarbons (PAHs), herbicides, and pesticides; simultaneously, Sedum alfredii Hance and alfalfa are the good remediation plants for the in-situ phytoremediation of polycyclic aromatic hydrocarbon in rural areas of North China; by adopting both phytodegradation and phytoextraction processes, the total PAH concentrations could be greatly decreased by $82.4 \%$ and $81.3 \%$ [51].

For heavily polluted soil cases, soil washing is an effective remediation approach $[52,53]$. This technology combines physical and chemical processes to remove heavy metals from contaminated soil by ex-situ washing soil with the eluent. During the washing process, the polluted soil is excavated from the contamination site and is washed by the injected eluent, during which chemical/biochemical solvents are also added to promote the pollutants dissolution or migration. Thus, pollutions, such as heavy metals, can be transferred easily from the soil phase to the liquid phase. The remediated soil will be returned to the original site, and the wasted washing effluent will be recycled for the subsequent soil wash processes or discharged to a wastewater treatment facility for disposal. Soil washing is of short duration and can be cost-effective, but not suitable for the soil with a fine (clay/powder) content of more than $25 \%$.

\section{Current research status of combined remediation technologies}

In the practical remediation process, only using one technology has several disadvantages and limitations; thus, techniques using combined methods to remediate heavily polluted surface water, groundwater, and soils have been attracting increasing attention. The typical combined remediation technologies are shown in Table 5.

An appropriate use of combined remediation technology can greatly improve the environmental restoration performance, and has a good applicational potential as well. In-situ bioremediation has been developed for polluted water and soil, but they possess some disadvantages, such as being time consuming and limited removal rate for the heavily polluted sites. In the surface water 


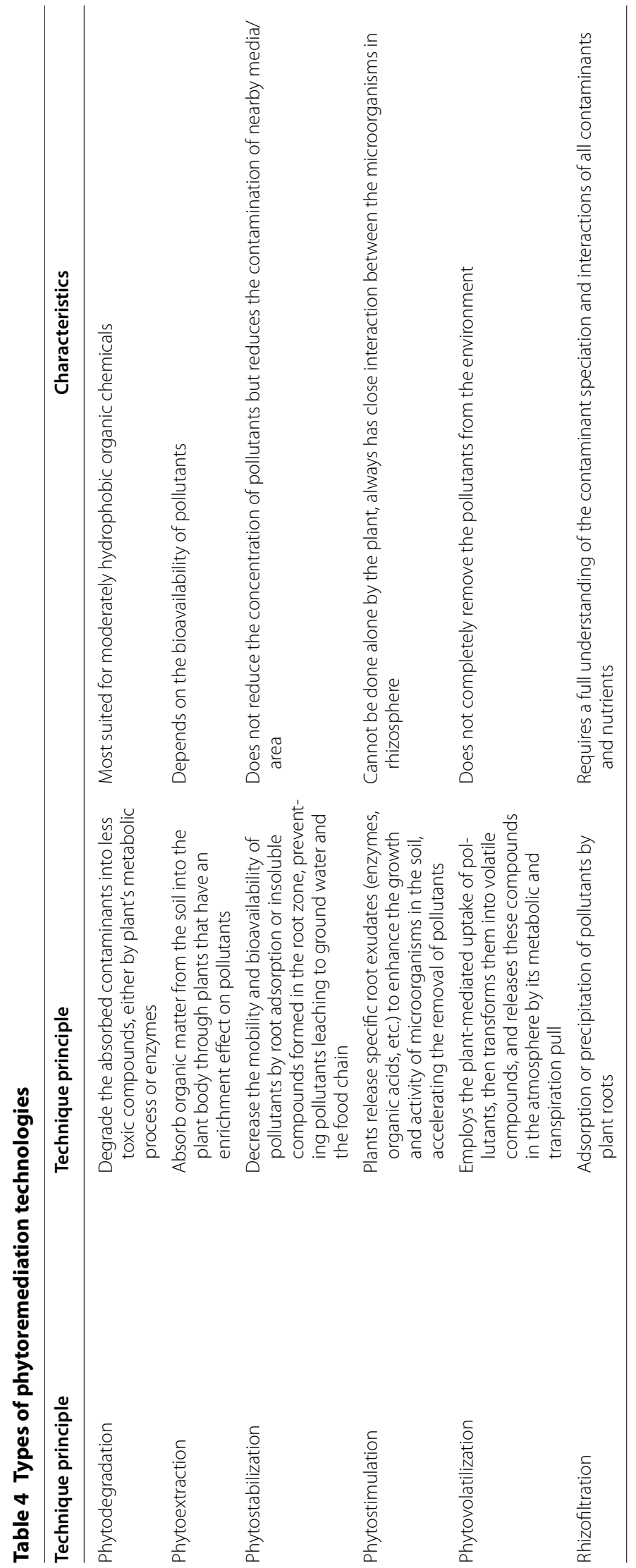


Table 5 Combined application of remediation technologies

\begin{tabular}{|c|c|}
\hline Combined remediation technique & Technique principle \\
\hline \multicolumn{2}{|l|}{ Surface water } \\
\hline Ecological restoration-aeration & $\begin{array}{l}\text { Aeration could improve the DO contents of polluted black-odor rivers to a certain extent, and had a } \\
\text { significant effect on the transformation of all forms of } \mathrm{N} \text { as well as the microbial activity }\end{array}$ \\
\hline Ecological floating bed-biofilm & Make full use of water vertical space, and provide more attaching surface area for microorganisms \\
\hline Ecological revetment_-ecological floating bed & $\begin{array}{l}\text { The ecological revetment intercepts a large amount of non-point source pollution carried by rainwa- } \\
\text { ter when it flows into the river, and the ecological floating bed further remediation river pollution }\end{array}$ \\
\hline \multicolumn{2}{|l|}{ Groundwater } \\
\hline Bioremediation coupled with nZVI & $\begin{array}{l}\text { The corrosion of nZVI creates a suitable reducing environment for the growth of anaerobic bacteria } \\
\text { and supplies electrons to the hydrogenotrophic bacteria and enhances the removal efficiency of } \\
\text { pollutants }\end{array}$ \\
\hline $\mathrm{UV} / \mathrm{H}_{2} \mathrm{O}_{2}$ photo-oxidation-aeration & $\begin{array}{l}\text { Volatilization, co-precipitation and biodegradation contributed to organic compounds removal dur- } \\
\text { ing the combined remediation process }\end{array}$ \\
\hline Bioelectroremediation & $\begin{array}{l}\text { The combination of anodic and cathodic redox environments with microbial metabolism paves the } \\
\text { way for the development of a variety of intriguing and beneficial removal pathways }\end{array}$ \\
\hline \multicolumn{2}{|r|}{ ( } \\
\hline Phyto-microorganism & $\begin{array}{l}\text { Microorganisms promote the extraction of heavy metals by plants and enhance the removal of } \\
\text { heavy metals in the sediment; The compartmentalization of heavy metals in microbial cells, chela- } \\
\text { tion, and fixation of metabolites can reduce the ability of heavy metals to migrate }\end{array}$ \\
\hline Phyto_-stabilizing agent & $\begin{array}{l}\text { The chemical stabilizing agent can change the existing forms of heavy metals in the through } \\
\text { adsorption or coprecipitation, improves the effect of phytoremediation of heavy metal polluted } \\
\text { sites }\end{array}$ \\
\hline Soil washing-effluent oxidation & $\begin{array}{l}\text { The surfactant was selected as washing agents to extract pollutant from contaminated soil samples. } \\
\text { After washing, the effluent containing surfactant and pollutants was collected further degradation } \\
\text { treatment using effluent oxidation technique }\end{array}$ \\
\hline Soil washing-freeze-thaw & $\begin{array}{l}\text { Destroy the original structure of soil particles by freeze-thaw, help the eluent fully interact with pol- } \\
\text { lutants, and thus improve washing efficiency }\end{array}$ \\
\hline
\end{tabular}

remediation process, the use of biofilm carriers in ecological floating bed could promote microbial richness and diversity, and many nitrifying and denitrifying bacteria would adhere to the biofilm carriers. Therefore, nitrification can be enhanced by $9-25 \%$, and the emissions of $\mathrm{N}_{2} \mathrm{O}$ and $\mathrm{CH}_{4}$ were reduced by $11-70 \%$ and $7-59 \%$, respectively [54]. For groundwater remediation, bioremediation was always combined with chemical remediation approaches using nanomaterials. The corrosion of nZVI could reduce the oxidation-reduction potential (ORP), which could create a suitable reductive environment for the growth of anaerobic bacteria, to completely degrade the contaminants into non-toxic or harmless substances [39]. In the process of soil plant-microorganism combined remediation, microorganisms can promote extraction and degradation of pollutants in the rhizosphere by changing the pollutant form and expanding the extension range of plant roots; meanwhile, plant root exudates in a natural environment can increase the organic matter content of the rhizosphere soil, contributing to a significant improvement in the activity of rhizosphere microorganisms as well as the biodegradation rate of pollutants in soil [55].

The other combined remediation techniques also developed successfully in recent years. For example, ecological remediation technology is also often combined with artificial gas exposure to improve the remediation effect. Fan et al. (2016) examined a horizontal subsurface flow-constructed wetland with intermittent aeration and showed that the average removal rates of COD, ammonia nitrogen, and total nitrogen could be improved to $95.6 \%$, $96.1 \%$, and $85.8 \%$, respectively [56]. Besides, aeration can strongly promote the removal efficiency of organic compounds in groundwater. The combination of $\mathrm{UV} / \mathrm{H}_{2} \mathrm{O}_{2}$ treatment and simple aeration was also demonstrated to be very effective for monoaromatic compounds, including chlorobenzene [57]. Similarly, Yan et al. (2015) effectively remediated nitrobenzene (NB)-contaminated soil using combined surfactant-enhanced soil washing and degradation of nitrobenzene (NB) in effluent with persulfate, with the NB removal rate of over 97\% [58].

\section{Planning progress of IR-RRNA project}

\section{Case history and description}

The main river network area YRD, located in East China, is one of the China's most developed, dynamic, densely populated, and concentrated industrial areas. In recent decades, the YRD has grown into an influential worldclass metropolitan area and played an important role in China's economic and social development. In general, the 
boundary of the YRD varies from different perspectives in terms of its culture, economy, or geography. This paper refers to the area composed of Shanghai, Jiangsu, and Zhejiang provinces.

Since 1970, owing to the strong Shanghai's industrial base, the cities along the Yangtze River have caught up in the development of non-agricultural industries through rural collective accumulation. In these rural areas, the "five small industries" (small-scale steel, machinery, chemical fertilizer, coal, and cement industries) were allowed and started to grow [59]. Since then, those towns with more rural industries became ideal places for farmers to work or do business in the YRD. Without exception, the YRD's rapid industrialization has huge impacts on its natural environment, i.e., water pollution, groundwater levels decline, and soil pollution have become prominent problems. According to the Shanghai Environmental Protection Agency in 2007, non-point source pollution has become the main factor affecting the stream quality of rural river network area, outpacing industrial point source pollution in the 1990s. Notably, because stream order and catchment boundaries are difficult to delineate in these river networks, the effect of land use on water quality may be quite different than that in other areas. Furthermore, the ecological degradation in the YRD is also serious, and the involved issues in terms of land degradation, loss of biodiversity, and serious ecological damage all have brought serious threats to human survival and sustainable development $[60,61]$.

\section{Research methodology and approach}

The IR-RRNA project aims to develop effective integrated remediation techniques and equipment for water environment remediation. It should first clarify the basic information, such as the typical pollution in the YRD, the pollution distribution and interactions between water and soil, and the migration and transformation mechanism of pollutants in the water/soil. Accordingly, the literature survey and the typical pollution investigation will be conducted in the RRNA, combined with the collection of the village type and environmental pollution data. A comprehensive analysis will then be conducted to elucidate the distribution of typical pollutants over the RRNA. The scientific principles of ecology, microbiology, and hydrology will be applied to study the process of the pollutant migration and transformation between SW-GW-Soil. Finally, the field pollution survey, experimental methodology, and computer simulation models will be integrated to clarify the migration process of flux between SW/GW, the transformation mechanism of pollutants, and the characteristics of the inner relationship. By this way, the regulation principle of surface, soil, and groundwater pollution remediation technology in RRNA will be revealed.

Based on the above theoretical study, bench-scale and pilot-scale tests will be conducted for polluted surface/ groundwater and soil remediation in RRNA. Combining with the theoretical and process analysis, as well as fitness-for-purpose assessment, three key remediation technologies will be formed for three different media with the advantages of "high efficiency, environmental friendliness, and economy": (1) aquatic plants and microorganism coupling strengthening remediation technology for surface water; (2) nZVI coupled biochar sustainedrelease remediation system for groundwater; and (3) high efficiency multi-dimensional continuous pollution soil remediation technology using plant-microbial and chemical stabilization. Simultaneously, the outcome of the pilot study will be combined with the theoretical analysis of technology process and pollutant characteristics, to explore the economical, applicable, and easy to hand equipment for the different rural environment remediations. Finally, one or two pollution scenarios will be simulated in RRNA, and systematically study the feasibility of using integrated remediation technology to remediate the contaminated surface/groundwater and soil under different influencing factors, and then establish an efficient and sustainable integrated remediation pilot system.

Considering that the in-situ contaminated environments are complicated and hard to simulate in the laboratory, a field demonstration will be carried out in the project. This field demonstration is characterized by the integrated remediation technique and will be implemented in rural river network areas in Shanghai. In consideration of the natural climate conditions and hydrological characteristics, the project will make full use of the spillover effect and carry out integrated remediation in typical pollution sites in RRNA. This platform will take consideration into the complexity of environmental medium and natural biogeochemical processes to form an environmental restoration system that is suitable for the different time and spatial scales, and finally to realize the integrated remediation for contaminated surface/ groundwater and soil in RRNA (Fig. 5).

\section{Key technologies and equipment for integrated remediation}

The RRNA remediation project supports the overall target of developing key techniques and devices for rural environmental remediation in RRNA. The selected remediation techniques, such as phytoremediation, microbiological remediation, nZVI/biochar remediation, and chemical stabilization, will be combined, regulated, and optimized to effectively restore the polluted water and 


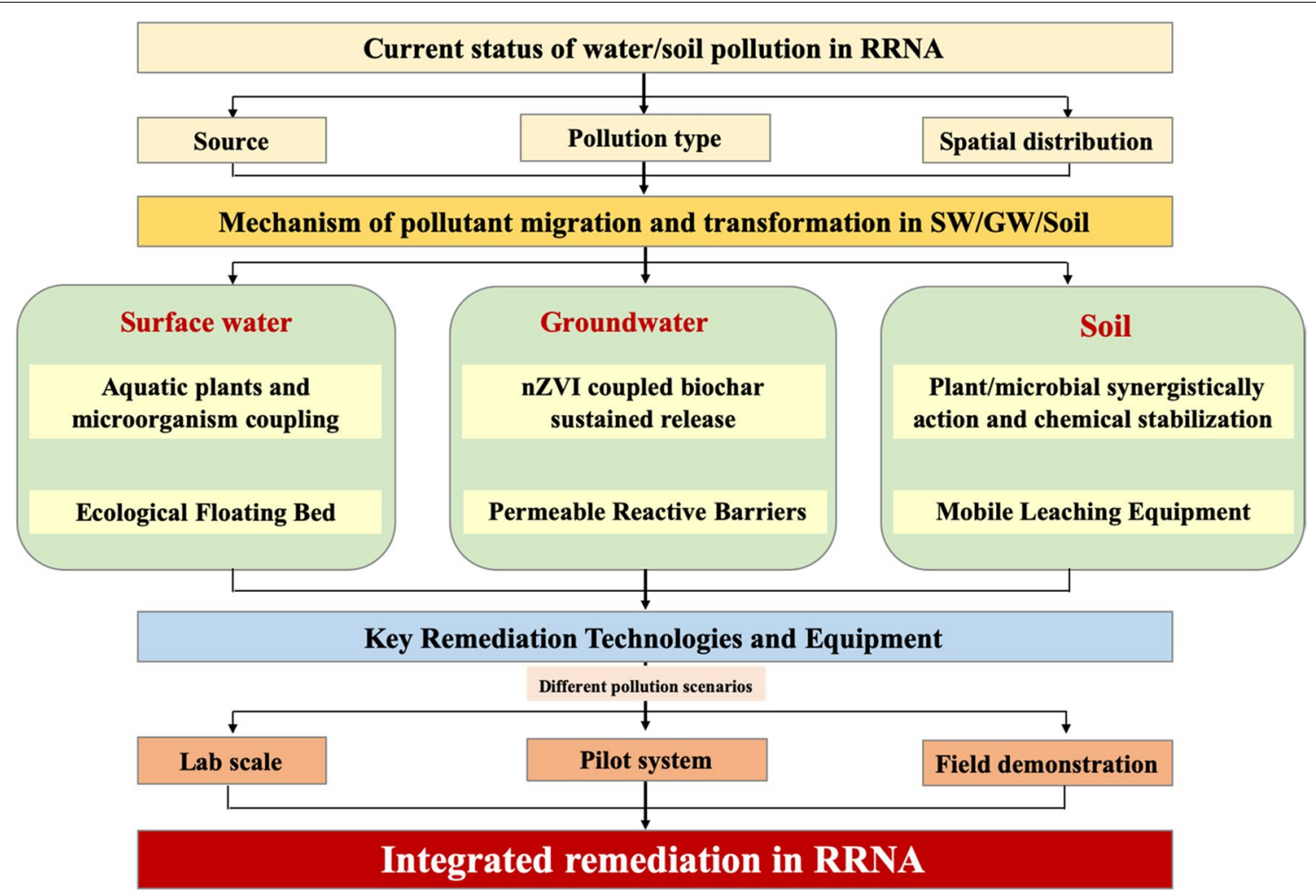

Fig. 5 Scheme of the conceptual framework of the IR-RRNA project

soil. Afterward, an integrated technical system will be created, including ecological reaction revetment, ecological floating bed, permeable reaction walls, mobile soil leaching device, and plant/roots-microorganism coupling remediation techniques, and ultimately to realize the efficient integrating of the plant, microorganism, and chemical stabilization for the contamination remediation in RRNA (Fig. 6).

River revetment is an important area of the land-water ecotone with comprehensive functions, such as safety protection, ecology, and landscape. It also acts as a connection channel between the river ecosystem and the terrestrial ecosystem. However, to accelerate the drainage of rainwater and protect the riverbank from soil erosion, a large number of riverbanks have been cut straight and channelized by constructing revetments in past years, resulting in serious damage of the ecological function of these riparian ecosystems [62]. Consideration of improved people's awareness in ecological and environmental protection as well as the preliminary filed investigation in RRNA, our project put forward an in-situ ecological reaction revetment construction plan. The outcome of this project could facilitate the sustainable circulation of SW/GW and river bank ecological restoration.
Eco-restoration materials for concrete revetment, aquatic plants, and PRBs are the main constitutes of the ecological reaction revetment. The native aquatic plants with a strong tolerance for pollutants will be selected to fix water pollutants via adsorption, accumulation, and degradation reactions. The plants' roots further provide a favorable habitat for microbial reproduction and stimulate microbial proliferation. Microbial consortia can help improve the water quality and maintain the stability of river slopes. In the laboratory, one or two native aquatic plants that with good pollution removal capacity will be chosen, and the plant/microbial interaction effect will be examined, based on which we attempt to develop an optimized strategy to effectively promote the mass and energy cycle among water/soil and plants/ microorganisms.

The PRBs that consist of nZVI/biochar sustainedrelease materials will be installed parallel to the revetment, in the path of a plume of contaminated surface and groundwater. Compared with the previous vertical installation method, it can dramatically drive down treatment costs and achieve better interception of pollutants in surface water. As the contaminants move through the $\mathrm{nZVI} /$ biochar material, the reaction occurs that transforms the contaminants into less harmful (non-toxic) or 


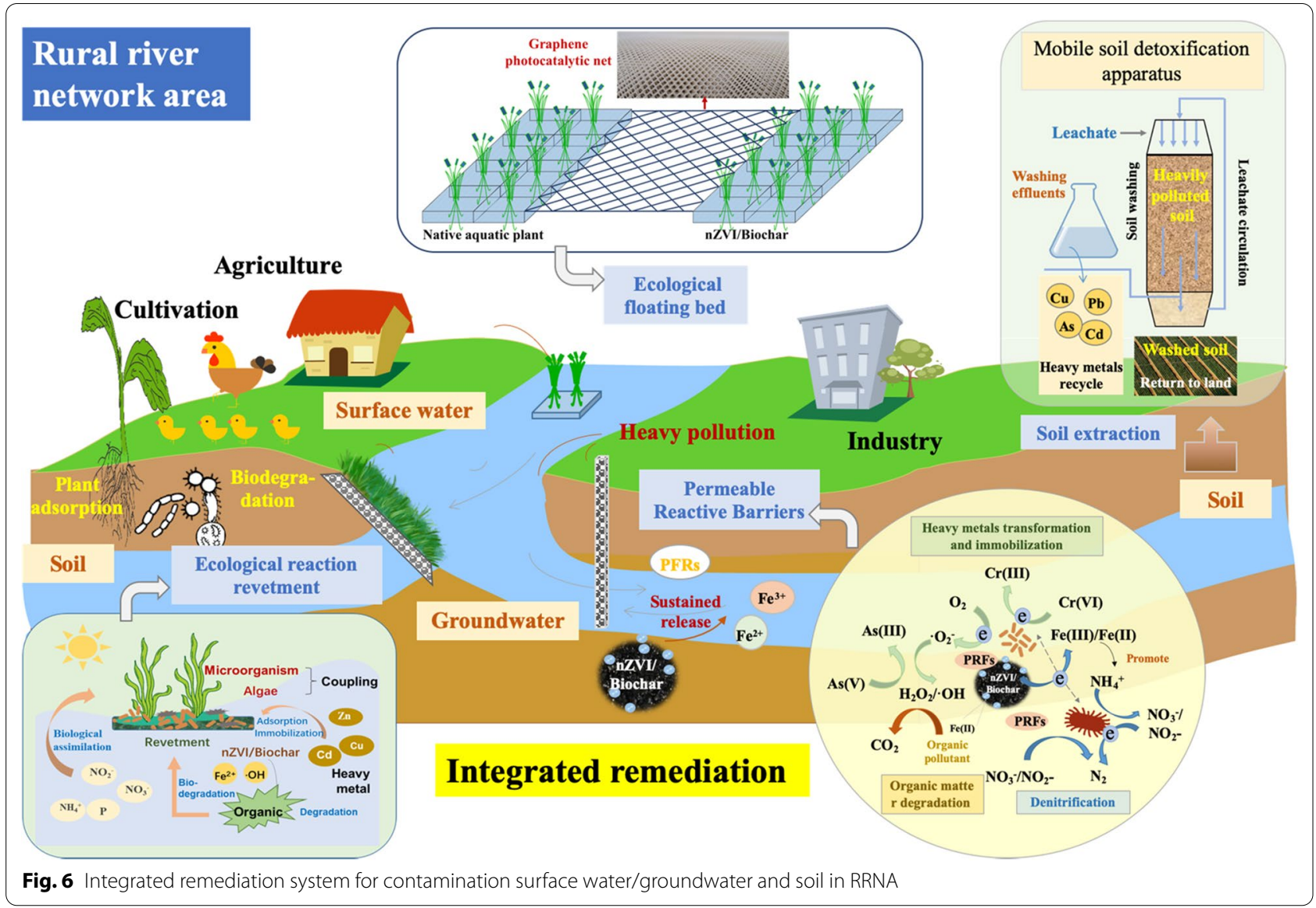

immobile species. For instance, nitrates will be reduced to $\mathrm{N}_{2}$ and/or $\mathrm{NH}_{4}{ }^{+}$by nZVI and the addition of biochar could be favorable for this process, as $\mathrm{NO}_{3}{ }^{-}$can be selectively reduced to $\mathrm{N}_{2}$ instead of $\mathrm{NH}_{4}^{+}[39,40]$. The PRBs are a barrier to the contaminants rather than a barrier to the groundwater. Therefore, PRBs should be designed to be more permeable than the surrounding aquifer materials so that the contaminants are removed as groundwater readily flows through but without significantly altering the groundwater hydrogeology.

Phytoremediation can improve the biological quality of the soil and has been recognized as a benign technology, so it has been selected for our project to degrade, accumulate, or stabilize of contaminants in the polluted aquatic systems. Prior to establishing the demonstration project, the native plant species that have an extremely high capacity of adsorption of metals will be selected firstly, affiliated with the microorganism-based remediation technologies to decompose, transform, and absorb pollutants. For the heavily polluted regions caused by long-term industrial production, the contaminated soil will be moved to a mobile soil washing device (a kind of ex-situ technique), and the contaminants (heavy metals) will be extracted and washed from soils by physical and/or chemical procedures. Meanwhile, a novel ecological floating bed has been proposed in our project that integrates graphene photocatalytic materials, act as a net between ecological floating bed.

The graphene, as a two-dimensional monolayer of sp2-bonded carbon atoms, was used for contaminants removals due to its large specific surface area, good charge transportation, and mechanical strength [63]. Then, the purification capacity and the stability of the ecological floating bed system can be greatly promoted, which favors flexibly to cope with the fluctuation of the water quality of the polluted river.

It should be noted that the integrated remediation system proposed in IR-RRNA project will fully consider the impact of pollution types, pollution levels, and hydrological conditions in different scenarios, and flexibly control the operation of the remediation system, to realize the optimal integration of surface/groundwater/ soil remediation in the RRNA in China. 


\section{Research prospect}

The implementation of the IR-RRNA project will form several key technologies, equipment, and integrated technical systems. These outcomes can more effectively support environmental monitoring and restoration in (Chinese) rural areas or (in China), ultimately favoring construction of "green livable village" of China. The benefits of this research mainly include the following: (i) The developed novel technologies, products, equipment, and remediation systems will be continuously applied to demonstration and supporting projects, which will create investment benefits by several times the research investment. (ii) The improvement of the water and soil environment quality in the rural area will greatly improve the people's quality of life which provides significant social benefits. (iii) The practice of the novel remediation technology will remediate the polluted environment, increase the value of natural resources in the environment and ecology, and provide a beautiful environment for the sustainable development of the rural area, which have good ecological benefits.

China is a large country with a vast land area, so the climate, hydrogeological conditions, and developing history in different Chinese regions vary greatly. Future research will take into consideration of the complex environmental medium and natural biogeochemical processes in different rural areas, to form an environmental restoration system that is suitable for different spatial scales in China, such as mountain areas and cold regions. Also, comprehensive environmental management and government policy are important means to achieve the harmony between human beings and nature. The effectively environmental management system will be perfected continuously in practice, and further serves for the construction of rural revitalization and eco-environment improvement.

\section{Conclusions}

In our project, multiple research methods, such as the multi-disciplinary theory application, in-situ sampling investigation, lab-/pilot-scale experiment, and integrated field determination, will be applied to develop an applicable integrated remediation technique and equipment for complex rural river network. The IR-RRNA project will clarify the key factors affecting the rural environment and address the urgent environmental problems in rural areas, based on which effective integrated remediation techniques will be developed to realize the integrated remediation of surface water/soil/groundwater. Our work highlights the importance of integrated environment remediation in the rural river network area. The outcome of the project hopes to favor realization of rural economic revitalization and ecological environment optimization.

\section{Abbreviations}

IR-RRNA: The integrated remediation in rural river network area project; RRNA: The rural river network area; SW: Surface water; GW: Groundwater; PRA: Participatory rural appraisal; WWP: Working with people; YRD: The Yangtze River Delta; PRD: The Pearl River Delta; MOST: The Ministry of Science and Technology of the People's Republic of China; EMR-rural: The environment monitoring and remediation in rural; PRBs: Permeable reactive barriers; $\mathrm{nZVl}$ : Nano zero-valent iron; NB: Nitrobenzene.

\section{Acknowledgements \\ The authors appreciate the contribution for all participants.}

\section{Authors' contributions}

HW contributed to conceptualization, investigation, writing original draft. TW contributed to writing original draft. GX, JZ,WM, YQ, and MW were involved in conceptualization, and writing--reviewing and editing. ZZ wrote original draft. PG, CS, BZ, and JY revised the manuscript; JG performed conceptualization, funding acquisition, and supervision. YW was involved in conceptualization, writing--reviewing and editing, funding acquisition, and supervision. All the authors read and approved the final manuscript.

\section{Funding}

This work was supported by the National Key R\&D Program of China (No: 2019YFD1100502)

\section{Availability of data and materials}

The datasets used and/or analyzed during the current study are available from the corresponding author on reasonable request.

\section{Ethics approval and consent to participate}

Not applicable.

\section{Consent for publication}

All the authors agreed to publish the paper.

\section{Competing interests}

The authors declare that they have no competing interests.

\section{Author details}

${ }^{1}$ State Key Laboratory of Pollution Control and Resources Reuse, Shanghai Institute of Pollution Control and Ecological Security, College of Environmental Science and Engineering, Tongji University, Siping Road, Shanghai 200092, People's Republic of China. ${ }^{2}$ College of Environmental Science and Engineering, State Environmental Protection Engineering Center for Pollution Treatment and Control in Textile Industry, Donghua University, Shanghai 201620, China. ${ }^{3}$ School of Energy Science and Engineering, Central South University, Changsha 410083, China. ${ }^{4}$ Key Laboratory of the Three Gorges Reservoir Region's Eco-Environment, College of Environment and Ecology, Chongqing University, Chongqing 400030, People's Republic of China.

Received: 14 September 2020 Accepted: 30 December 2020 Published online: 09 January 2021

\section{References}

1. Adelodun B, Ajibade FO, Ighalo JO, Odey G, Ibrahim RG, Kareem KY, Bakare HO, Tiamiyu AO, Ajibade TF, Abdulkadir TS, Adeniran KA (2020) Assessment of socioeconomic inequality based on virus-contaminated water usage in developing countries: a review. Environ Res 192:110309

2. Xie W, Zhao J, Zhang Q, Ye C, Zheng G, Shan Q, Shao X (2020) Occurrence, distribution and bioaccumulation of alkylphenols in the Pearl River networks South China. Ecol Indic 110:105847

3. Xu Z, Xu J, Yin H, Jin W, Li H, He Z (2019) Urban river pollution control in developing countries. Nat Sustain 2(3):158-160 
4. OECD. Regional development-Rural Development. 2002. http://www. oecd.org/governance/regional-policy/ruraldevelopment.htm.

5. Cazorla A, De Los Rl, Salvo M (2013) Working with people (WWP) in rural development projects: a proposal from social learning. Cuad Desarro Rural 10(SPE70):131-157

6. Chambers $R$ (1994) The origins and practice of participatory rural appraisal. World Dev 22(7):953-969

7. Gu C, Hu L, Zhang X, Wang X, Guo J (2011) Climate change and urbanization in the Yangtze River Delta. Habitat Int 35(4):544-552

8. Wei C, Taubenböck H, Blaschke T (2017) Measuring urban agglomeration using a city-scale dasymetric population map: a study in the Pearl River Delta, China. Habitat Int 59:32-43

9. LiY, Wu F (2018) Understanding city-regionalism in China: Regional cooperation in the Yangtze River Delta. Reg Stud 52(3):313-324

10. Ministry of Ecology and Environment of People's Republic of China. Report on the State of the Environment in China 2013-2018; 2019. http://www.mee.gov.cn/hjzl/sthjzk/zghjzkgb/. Accessed 15 Aug 2019.

11. Guo SL (2019) Application of underwater ecosystem construction in rural river regulation in plain river network area. Dissertation, Zhejiang Universtiy.

12. Song S, Xu YP, Wu ZF, Deng XJ, Wang Q (2019) The relative impact of urbanization and precipitation on long-term water level variations in the Yangtze River Delta. Sci Total Environ 648:460-471

13. Han L, Xu Y, Lei C, Yang L, Deng X, Hu C, Xu G (2016) Degrading river network due to urbanization in Yangtze River Delta. J Geogr Sci 26(6):694-706

14. Gatel L, Lauvernet C, Carluer N, Paniconi C (2016) Effect of surface and subsurface heterogeneity on the hydrological response of a grassed buffer zone. J Hydrol 542:637-647

15. Yan SF, Yu SE, Wu YB, Pan DF, She DL, Ji J (2015) Seasonal variations in groundwater level and salinity in coastal plain of eastern China influenced by climate. J Chem. https://doi.org/10.1155/2015/905190

16. JrB C, Robinson CE, Hinton MJ, Russell HA (2019) A framework for conceptualizing groundwater-surface water interactions and identifying potential impacts on water quality, water quantity, and ecosystems. J Hydrol 574:609-627

17. Greene RS, Hairsine PB (2004) Elementary processes of soil-water interaction and thresholds in soil surface dynamics: a review. Earth Surf Proc Land 29(9):1077-1091

18. Chen Z, Shao Y, He M, Liang J, Jiang Y, Wang Y, Zhou M, Gong Z, Zhou X Fang F, Guo J (2020) The EMR-rural project: key techniques and devices' development for rural environmental monitoring and remediation in China. Environ Sci Eur 32(1):1-9

19. Pekel JF, Cottam A, Gorelick N, Belward AS (2016) High-resolution mapping of global surface water and its long-term changes. Nature 540(7633):418-422

20. Domagalski JL, Morway E, Alvarez NL, Hutchins J, Rosen MR, Coats R (2020) Trends in nitrogen, phosphorus, and sediment concentrations and loads in streams draining to Lake Tahoe, California, Nevada, USA. Sci Total Environ 752:141815

21. Adapa LM, Azimi Y, Singh S, Porcelli D, Thompson IP (2016) Comparative study of chemical and physical methods for distinguishing between passive and metabolically active mechanisms of water contaminant removal by biofilms. Water Res 101:574-581

22. Wu J, Xu Z, Li H, Li P, Wang M, Xiong L, Zhang J (2019) Long-term effect of water diversion and CSOs on the remediation of heavy metals and microbial community in river sediments. Water Sci Technol 79(12):2395-2406

23. Camacho FP, Sousa VS, Bergamasco R, Teixeira MR (2017) The use of Moringa oleifera as a natural coagulant in surface water treatment. Chem Eng J 313:226-237

24. Sánchez-Martín J, González-Velasco M, Beltrán-Heredia J (2010) Surface water treatment with tannin-based coagulants from Quebracho (Schinopsis balansae). Chemi Eng J 165(3):851-858

25. MacArthur M, Naylor LA, Hansom JD, Burrows MT (2020) Ecological enhancement of coastal engineering structures: Passive enhancement techniques. Sci Total Environ 740:139981

26. Wang H, Li Z, Han H (2017) Comparison of different ecological remediation methods for removing nitrate and ammonium in Qinshui River, Gonghu Bay. Taihu Lake Environ Sci Pollut R 24(2):1706-1718
27. Irwin NB, Irwin EG, Martin JF, Aracena P (2018) Constructed wetlands for water quality improvements: benefit transfer analysis from Ohio. J Environ Manage 206:1063-1071

28. Song J, Li Q, Dzakpasu M, Wang XC, Chang N (2020) Integrating stereoelastic packing into ecological floating bed for enhanced denitrification in landscape water. Bioresour Technol 299:122601

29. Sun S, Sheng Y, Zhao G, Li Z, Yang J (2017) Feasibility assessment: application of ecological floating beds for polluted tidal river remediation. Environ Monit Assess 189(12):609

30. Lin H, Liu J, Dong Y, He Y (2019) The effect of substrates on the removal of low-level vanadium, chromium and cadmium from polluted river water by ecological floating beds. Ecotox Environ Safe 169:856-862

31. Winter TC (1999) Relation of streams, lakes, and wetlands to groundwater flow systems. Hydrogeol J 7(1):28-45

32. Qin D, Qian Y, Han L, Wang Z, Li C, Zhao Z (2011) Assessing impact of irrigation water on groundwater recharge and quality in arid environment using CFCs, tritium and stable isotopes, in the Zhangye Basin Northwest China. J Hydrol 405(1-2):194-208

33. Lasagna M, De Luca DA, Franchino E (2016) Nitrate contamination of groundwater in the western Po Plain (Italy): the effects of groundwater and surface water interactions. Environ Earth Sci 75(3):240

34. Mackay DM, Cherry JA (1989) Groundwater contamination: pump-andtreat remediation. Environ Sci Technol 23(6):630-636

35. Chang LC, Chu HJ, Hsiao CT (2007) Optimal planning of a dynamic pumptreat-inject groundwater remediation system. J Hydrol 342(3-4):295-304

36. Baciocchi R, D'Aprile L, Innocenti I, Massetti F, Verginelli I (2014) Development of technical guidelines for the application of in-situ chemical oxidation to groundwater remediation. J clean prod 77:47-55

37. Levakov I, Ronen Z, Dahan O (2019) Combined in-situ bioremediation treatment for perchlorate pollution in the vadose zone and groundwater. J Hazard Mater 369:439-447

38. PakT, Archilha NL, de Lima Luz LF (2019) Nanotechnology-based remediation of groundwater. Nanotechnology characterization tools for environment, health, and safety. Springer, Berlin, pp 145-165

39. Dong H, Li L, Lu Y, Cheng Y, Wang Y, Ning Q, Wang B, Zhang L, Zeng G (2019) Integration of nanoscale zero-valent iron and functional anaerobic bacteria for groundwater remediation: a review. Environ Int 124:265-277

40. Tasharrofi S, Rouzitalab Z, Maklavany DM, Esmaeili A, Rabieezadeh M, Askarieh M, Rashidi A, Taghdisian H (2020) Adsorption of cadmium using modified zeolite-supported nanoscale zero-valent iron composites as a reactive material for PRBs. Sci Total Environ 736:139570

41. Obiri-Nyarko F, Grajales-Mesa SJ, Malina G (2014) An overview of permeable reactive barriers for in situ sustainable groundwater remediation. Chemosphere 111:243-259

42. Kiel BA, Cardenas MB (2014) Lateral hyporheic exchange throughout the Mississippi River network. Nat Geosci 7(6):413-417

43. de Mello K, Valente RA, Randhir TO, dos Santos ACA, Vettorazzi CA (2018) Effects of land use and land cover on water quality of low-order streams in Southeastern Brazil: watershed versus riparian zone. CATENA 167:130-138

44. Mirsal IA (2008) Soil pollution. Springer, Berlin

45. National Soil Pollution Status Survey Bulletin (2014) Beijing: Ministry of Land and Resources of the People's Republic of China and Ministry of Environmental Protection.

46. Wang H, Zeng Y, Guo C, Bao Y, Lu G, Reinfelder JR, Dang Z (2018) Bacterial, archaeal, and fungal community responses to acid mine drainage-laden pollution in a rice paddy soil ecosystem. Sci Total Enviro 616:107-116

47. Gidudu B, Chirwa EMN (2020) The combined application of a high voltage, low electrode spacing, and biosurfactants enhances the bioelectrokinetic remediation of petroleum contaminated soil. J Clean Prod 276:122745

48. Rui D, Wu Z, Ji M, Liu J, Wang S, Ito Y (2019) Remediation of Cd-and Pbcontaminated clay soils through combined freeze-thaw and soil washing. J Hazard Mater 369:87-95

49. Cui H, Li H, Zhang S, Yi Q, Zhou J, Fang G, Zhou J (2020) Bioavailability and mobility of copper and cadmium in polluted soil after phytostabilization using different plants aided by limestone. Chemosphere 242:125252

50. Zhang Q, Kong W, Wei L, Wang Y, Luo Y, Wang P, Liu J, Schnoor JL, Jiang G (2020) Uptake, phytovolatilization, and interconversion of 2, 4-dibromophenol and 2, 4-dibromoanisole in rice plants. Environ Int 142:105888 
51. Ma J, Gao C, Yan H, Li Y, Chen J, Zhao Y, Xia X (2019) Characteristics, sources, and in situ phytoremediation of polycyclic aromatic hydrocarbon in rural dumpsites. J Soil Sediment 19(12):3945-3953

52. Zhai X, Li Z, Huang B, Luo N, Huang M, Zhang Q, Zeng G (2018) Remediation of multiple heavy metal-contaminated soil through the combination of soil washing and in situ immobilization. Sci Total Environ 635:92-99

53. Feng W, Zhang S, Zhong Q, Wang G, Pan X, Xu X, Zhou W, Li T, Luo L, Zhang $Y$ (2020) Soil washing remediation of heavy metal from contaminated soil with EDTMP and PAA: properties, optimization, and risk assessment. J Hazard Mater 381:120997

54. Sun S, Liu J, Zhang M, He S (2019) Simultaneous improving nitrogen removal and decreasing greenhouse gas emission with biofilm carriers addition in ecological floating bed. Bioresour Technol 292:121944

55. Gu W, Zhao Y, Li Q, Li Y (2020) Plant-microorganism combined remediation of polychlorinated naphthalenes contaminated soils based on molecular directed transformation and Taguchi experimental designassisted dynamics simulation. J Hazard Mater 396:122753

56. Fan J, Zhang J, Guo W, Liang S, Wu H (2016) Enhanced long-term organics and nitrogen removal and associated microbial community in intermittently aerated subsurface flow constructed wetlands. Bioresour Technol 214:871-875

57. Lhotský $O$, Krákorová E, Mašín P, Žebrák R, Linhartová L, Křesinová Z, Kašlík J, Steinová J, Rødsand T, Filipová A, Petrů K, Kroupová K, Cajthaml T (2017) Pharmaceuticals, benzene, toluene and chlorobenzene removal from contaminated groundwater by combined $\mathrm{UV} / \mathrm{H}_{2} \mathrm{O}_{2}$ photo-oxidation and aeration. Water Res 120:245-255

58. Yan J, Gao W, Qian L, Han L, Chen Y, Chen M (2015) Remediation of nitrobenzene contaminated soil by combining surfactant enhanced soil washing and effluent oxidation with persulfate. PLoS ONE 10(8):e0132878

59. Wong CPW (1980) Rural industrialization in China: development of the" five small industries". Dissertation Abstracts International A: 40(8).

60. Zhao J, Lin L, Yang K, Liu Q, Qian G (2015) Influences of land use on water quality in a reticular river network area: a case study in Shanghai, China. Landsc Urban Plan 137:20-29

61. Che Y, Yang K, Wu E, Shang Z, Xiang W (2012) Assessing the health of an urban stream: a case study of Suzhou Creek in Shanghai China. Environ Monit Assess 184(12):7425-7438

62. Yan L, Xie C, Xu X, Che S (2019) Effects of revetment type on the spatial distribution of soil nitrification and denitrification in adjacent tidal urban riparian zones. Ecol Eng 132:65-74

63. Zheng Q, Kim JK (2015) Graphene for transparent conductors: Synthesis, properties and applications, vol 23. Springer, Berlin

\section{Publisher's Note}

Springer Nature remains neutral with regard to jurisdictional claims in published maps and institutional affiliations.

\section{Submit your manuscript to a SpringerOpen ${ }^{\circ}$ journal and benefit from:}

- Convenient online submission

- Rigorous peer review

- Open access: articles freely available online

- High visibility within the field

- Retaining the copyright to your article

Submit your next manuscript at $\boldsymbol{\nabla}$ springeropen.com 